\title{
Yield and Quality of Fertigated Papaya Fruits Submitted to Potassium Doses in Northeast Pará
}

\author{
Valdeides Marques Lima (Corresponding author), Joaquim Alves de Lima Junior, Antonia \\ Benedita da Silva Bronze, William Lee Carrera de Aviz, Aristóteles Pires de Matos, Lidiane \\ de Souza Silva, Danilo da Luz Melo \\ Universidade Federal Rural da Amazônia - UFRA, Brasil
}

Received: Dec. 23, 2019 Accepted: Feb. 16, $2020 \quad$ Published: Mar. 6, 2020

doi:10.5296/jas.v8i3.16107～URL: https://doi.org/10.5296/jas.v8i3.16107

\begin{abstract}
The objective of this work was to evaluate the effect of potassium doses supplied via fertigation on yield and fruit quality of Solo papaya, cultivar THB. The experiment was installed in August 2018 in the Experimental Station of the Federal Rural University of Amazonia, Municipality of Igarapé-Açu, State of Para, Brazil, and lasted for 13 months. The experiment was conducted in completely randomized design with four replications and treatments applications started in the fifth month after planting. Treatments were four doses of $\mathrm{K}_{2} \mathrm{O}\left(160,320,480\right.$ and $\left.640 \mathrm{~kg} \mathrm{~K}_{2} \mathrm{O} \mathrm{ha}{ }^{-1}\right)$ that correspond to 50, 100, 150 and $200 \%$ of recommended dose based on soil analysis. Potassium was supplied in the form of $\mathrm{KNO}_{3}$, in the irrigation water, associated to the others fertilizers. During the five month harvest period, the papaya yield reached $22.3 \mathrm{t} \mathrm{ha}^{-1}$, fruit number was $67,776 \mathrm{fruit}^{-1}$, fruit weight was about $418.6 \mathrm{~g}$ and soluble solid titratable acidity ratio as high as 13.9.
\end{abstract}

Keywords: Carica papaya L., potassium nitrate, plant nutrition

\section{Introduction}

Papaya (Carica papaya L.) is one of the most common fruit crops in almost all Tropical America Countries. It was first found by Spanish people in a region located from South Mexico to North of Nicaragua. From there papaya was brought to several regions located at $32^{\circ}$ of latitude North and South. It seems that the papaya introduction in Brazil occurred by 1587 (Serrano \& Cattaneo, 2010).

The most planted cultivars of papaya in Brazil belong to the groups Solo and Formosa. Solo cultivars present high endogamy potential, their fruits are small (around 0.350 to $0.700 \mathrm{~kg}$ ) appropriated for domestic market and mainly for international trade. The municipalities of Linhares and Sooretama, State of Espírito Santo, are the largest Solo papaya producers in Brazil, growing the cultivars Golden and Golden THB for export, and Sunrise Solo for 
domestic consumption (Serrano \& Cattaneo, 2010; Oliveira et al., 2008; Manica et al., 2006; Oliveira et al., 2004).

The papaya production worldwide in 2017 was 13.24 million ton. India, Brazil, Mexico, Indonesia and Dominican Republic were the most important producers. The Brazilian papaya production was $1,057,101$ ton, corresponding to $7.98 \%$ of total world papaya production. Brazil ranks fourth place related to planted area, 26,526 ha, and seventh on yield with $39.85 \mathrm{t}$ $\mathrm{ha}^{-1}$. At national level, the State of Para ranks ninth place related to production, contributing with $1.26 \%$ of the total Brazilian papaya production. The papaya yield of the State of Para is considered low, only $17.83 \mathrm{t} \mathrm{ha}^{-1}$, thus laying it in the fifteenth place among the papaya producers States of Brazil (FAOSTAT, 2017; IBGE, 2018)

The development of the papaya industry in Brazil increases proportionally with the insertion of new production technologies but there are still problems to be overcome in order to reach the ideal situation. Silva (2014) agree with the assumption that the expansion of the papaya production area in Brazil and its increase in yield are related directly to the insertion of improved production technologies able to promote better taste and fruit quality as well as higher income rate, enabled by higher yield and favorable conditions of domestic and international markets.

Adequate fertilization is an important component on the production technology and potassium is considered the nutrient of the quality of the production, since it plays important roles on increasing fruit size, peel thickness, titratable acidity, root development, control of tissue turgidity, opening and closing of stomata, carbohydrate transport, protein synthesis, and acts improving plant reaction to diseases. Thus it is important nutrient to obtain maximum economic yield (Shimazaki et al., 2007; Araújo et al., 2005; Soares et al., 2005).

Irrigation is considered also as a production technology that makes possible to increase papaya production significantly, enables papaya cultivation in regions where water availability in the soil is low, contributes for generation of employment and income, reduces the migration from rural to urban areas and raises the farmland value. Whoever, studies have been shown that about $50 \%$ of the water volume used for irrigation is lost, thus irrigation must be performed under technical criteria in order to reach good efficiency (Feitosa et al., 2018; Lima et al., 2015; Sousa, et al., 2014).

The association of irrigation and fertigation makes possible to supply the nutrients at the right time, according to the crop requirements, thus adjusting the crop nutritional demand, with reduced losses of nutrients for lixiviation, fixation and volatilization, as well as increases the fertilization efficiency. Whoever, setting the fertigation scheme requires good knowledge of the crop nutritional requirements, taking into account that environmental conditions varies from place to place interfering on the crop response (Sousa, et al., 2014).

The objective of this work was to evaluate the effect of four doses of potassium, supplied via fertigation, on the development and production of the papaya crop, cultivar THB. 


\section{Materials and Methods}

The experiment was carried out in the Experimental Station of the Federal Rural University of Amazonia (UFRA), Municipality of Igarapé-Açu, State of Para, located at $1^{\circ} 07^{\prime} 48,47^{\prime \prime} \mathrm{S}$ e $47^{\circ} 36^{\prime} 45,31^{\prime \prime} \mathrm{W}, 54 \mathrm{~m}$ of altitude above sea level.

Climate in the region is Ami type, according to Köppen's classification, hot and humid, annual average temperature ranging from 25 to $32 \mathrm{C}$ and annual rainfall from 2,500 to 3,000mm (Pachêco; Bastos, 2011).

Environmental data were collected by an automatic portable meteorological station (Vantage Pro2, Davis), placed around de experimental area. Data were collected every 2.5 seconds and total means calculated for each 15 minutes.

The soil of the experimental area was classified as an Argisol Yellow Dystrophic with average sand texture. Chemical and physical soil analyses were carried out in samples collected at 0-20 and 20-40 cm. Results are shown in Table 1.

Table 1. Results of physical and chemical soil analysis of the experimental area. (1)

\begin{tabular}{|c|c|c|c|c|c|c|c|c|c|c|c|c|}
\hline \multirow{3}{*}{ Depth } & \multicolumn{12}{|c|}{ Attributes } \\
\hline & pH & \multicolumn{2}{|c|}{ Saturation } & \multicolumn{2}{|c|}{ CTC } & \multirow{2}{*}{$\mathbf{C a}$} & \multirow{2}{*}{$\mathrm{Ca}+\mathrm{Mg}$} & \multirow{2}{*}{ Al } & \multirow{2}{*}{$\mathbf{H}+\mathbf{A l}$} & \multirow{2}{*}{$\mathbf{P}$} & \multirow{2}{*}{$\mathbf{K}$} & \multirow{2}{*}{$\mathbf{N a}$} \\
\hline & & Base & Aluminum & Total & Efetiva & & & & & & & \\
\hline$(\mathbf{c m})$ & $\Pi_{2} \mathrm{U}$ & $\mathrm{v \%}$ & $\mathbf{m} \%$ & \multicolumn{6}{|c|}{ - - } & \multicolumn{3}{|c|}{$---\left(\mathrm{mg} \mathrm{dm}^{-3}\right)$} \\
\hline $0-20$ & 5.24 & 39.56 & 5.68 & 0.06 & 13.76 & 1.75 & 2.45 & 0.11 & 2.79 & 13 & 19 & 7 \\
\hline $0-40$ & 5.02 & 41.26 & 13.91 & 0.06 & 13.76 & 1.14 & 1.55 & 0.19 & 1.67 & 4 & 6 & 5 \\
\hline
\end{tabular}

(1) Embrapa Amazônia Oriental Soil Analysis Laboratory

The papaya cultivar THB, used in this work, belongs to the Solo group, shows good vegetative uniformity, high yield and good response to pests and diseases. Commercial fruits are pear shaped, $150 \mathrm{~mm}$ long and $87 \mathrm{~mm}$ diameter, flesh is orange color and firm. Harvest started at eight months after planting when plants were not so high which made harvest easy.

The experiment design was randomized block with four replications. Treatments were as follows: $160 \mathrm{~kg} \mathrm{~K}_{2} \mathrm{O} \mathrm{ha}{ }^{-1}$ (50\% recommended dose based on soil analysis); $320 \mathrm{~kg} \mathrm{~K}_{2} \mathrm{O} \mathrm{ha}^{-1}$ (100\% recommended dose based on soil analysis); $480 \mathrm{~kg} \mathrm{~K}_{2} \mathrm{O} \mathrm{ha} \mathrm{ha}^{-1}$ (150\% recommended dose based on soil analysis); and $640 \mathrm{~kg} \mathrm{~K}_{2} \mathrm{O} \mathrm{ha}^{-1}$ (200\% recommended dose based on soil analysis). Experimental plots were $6.00 \times 7.00 \mathrm{~m}$ with seven plants, spacing 2 x 2 x $4 \mathrm{~m}$. data were collected in three plants per plot.

Field preparation was according to growers system, such as repeated ploughing. Sixty days before planting, based on the soil analysis, limy was applied to the soil at a rate of 1.85 ton $\mathrm{ha}^{-1}$, aiming at correcting soil acidity and elevating base saturation to $80 \%$. Fertilization from planting up to five months after planting, based on soil analysis, consisted on $60 \mathrm{~kg} \mathrm{~N}, 30 \mathrm{~kg}$ $\mathrm{P}_{2} \mathrm{O}_{5}$ e $80 \mathrm{~kg} \mathrm{~K} 2 \mathrm{O}$, per hectare; all phosphorus was applied at once before planting while $\mathrm{N}$ and $\mathrm{K}$ were applied in three splits. $\mathrm{N}$ and $\mathrm{K}$ were applied in the form of urea and potassium chloride, respectively while phosphorus was in the form of triple super phosphate. 
Additionally, there were performed four foliar applications of $\mathrm{K}(1 \%), \mathrm{Mg}(2 \%), \mathrm{B}(3) \%, \mathrm{Fe}$ (1\%), Mn (7\%), Mo (0,2\%), Zn (10\%), and S (12,7\%) with $260 \mathrm{~g} \mathrm{~L}^{-1} \quad$ solubility, according to the recommendation of $1,5 \mathrm{~kg}$ ha- 1 . Starting at the fifth month after planting, January 2019 , fertilization was performed via fertigation following the recommendation of $280 \mathrm{~kg} \mathrm{~N}, 60 \mathrm{~kg}$ $\mathrm{P}_{2} \mathrm{O}_{5}$ e $320 \mathrm{~kg} \mathrm{~K} 2 \mathrm{O}$ per hectar in the form of urea, purified monoammonium phosphate (MAP) and potassium nitrate, respectively, maintaining foliar application once a month (Sousa et al,; 2014).

Pests and disease monitoring were performed every two weeks. Dithiocarbamate fungicide, $200 \mathrm{~g} 100 \mathrm{~L}^{-1}$, was sprayed to control fungal diseases, starting four month after planting. Mite management was based on spraying abamectin insecticide.

Up to four month after planting the following cultural practices were performed: hoeing, application of sheep manure $3 \mathrm{~kg}$ per plant, and heaps. From the fifth month on weed management was based on three glyphosate applications over the period of conduction of the experiment aiming at reduction of production costs, avoiding possible problems of the irrigation system and keeping the pots individualized, thus favoring treatment application.

Up to the fifth month after planting irrigation water was provided by santeno hose with a discharge rate of $2.5 \mathrm{~mm} /$ day. From the fifth month on a drip irrigation system was used to provide the fertigation. Papaya plant sexing was performed five months after planting when male and female plants were removed leaving the hermaphrodite ones.

Irrigation and fertigation system consisted of a water tank of 5,000 L; a centrifugal motor pump $1 \frac{1}{2} \mathrm{~h}$ p; one filter; two manometers for water pressure control, one set before the filter and the other after it. The suction and repression line was a $32 \mathrm{~mm}$ PVC pipe. Outside the motor pump house the repression line was expanded to $50 \mathrm{~mm}$ PVC blue pipe PN40 and such a diameter was maintained up to plots individualization. In order to conduct irrigation water to each plot it was used a $16 \mathrm{~mm}$ polyethylene pipe and the water release was controlled by a registry of equal diameter. Four drip hoses, $16 \mathrm{~mm}$ diameter, were distributed in each plot, being two drip hoses for papaya planting row. Drippers were spaced $15 \mathrm{~cm}$ from each other, 186 total drippers per plot, with an average water discharge rate of $1.4 \mathrm{~L} \mathrm{~h}^{-1}$ per dipper, at 10.0 m.c.a. pressure, which corresponds to 14.226 psi.

The scheduling interval of fertigation of the $\mathrm{K}$ doses was followed at biweekly interval, starting from five month after transplanting in the main field. Fertigation system consisted of a water tank, $50 \mathrm{~L}$ capacity, coupled to the pipeline that connect the water tank to the motor pump. Water to the tank was supplied by a pipeline connected to the repression part, just over the motor pump. Both refilling and supplying the nutrient solution to the irrigation system were controlled by manual registries.

Determination of the uniformity distribution coefficient (UDC) was based on the water volume collected from two drippers located in the center of the plot, total of 40 samples per plot, using the following formula: 


$$
\text { CUD }=\frac{q 25}{q m} \times 100
$$

In which: UDC - uniformity distribution coefficient (\%); q25 - mean of $1 / 4$ of discharges with the lower values; qm - overall mean.

Harvest started by mid April 2019, around four months after plant sexing, and it continued at a biweekly interval. Fruits were harvested at stage 1 ripening, that is skin changing from green to yellow.

Data were recorded in various parameters as follows: yield determined on base of total fruit weight of each plot (TFW ha-1); total number of fruits harvested (NFH ha' ${ }^{-1}$ ); number of marketable fruits (NMF ha-1) represented by well formed and healthy looking fruits with more than $300 \mathrm{~g}$; yield of marketable fruits based on weight of marketable fruits (YMF ha-1); plant height $(\mathrm{PH})$; and water efficiency use (WEU). For biometry data, sample containing three fruits per each plot were collected and the following parameters were evaluated: fruit length measured from base to apex (FL); fruit diameter measured at the medium region (FD); and fruit weight $(\mathrm{FW})$. Fruit length and diameter were determined by using a pachymeter and fruit weight using a digital balance, $5 \mathrm{~g}$ accuracy. Chemical analysis of papaya fruits was performed at the Agricultural Technology Center, Federal Rural University of Amazonia. Fruits, stage 3 ripening (Ritzinger \& Souza, 2000), were stored under $20 \mathrm{C} \pm 1$ conditions until evaluation for the following parameters: soluble solids (SS) were determined using an analogic refractometer, value expressed in ${ }^{\circ} \mathrm{Brix}$; $\mathrm{pH}$ was measured in a $\mathrm{pH}$ meter JK-PHM-005 High-Precision model; titratable acidity (TA) was determined by volumetric titration using $\mathrm{NaOH} 0.9899 \mathrm{~N}$; and SS/TA calculated by dividing SS by TA.

Data were submitted to statistical analysis, AgroEstat Online Program (Maldonado, Jr. W., 2019), and means compared by Tukey test $5 \%$ probability.

\section{Results and Discussion}

\subsection{Analysis of Variance (ANOVA)}

Table 2 shows analysis of variance of the variables related to fruit biometry and yield. There was overall significant effect of $\mathrm{K}$ doses on the evaluated variables except for fruit diameter which showed non-significant effect for $\mathrm{K}$ doses. 


\section{Macrothink}

Journal of Agricultural Studies

ISSN 2166-0379

2020, Vol. 8, No. 3

Table 2. Effect of $\mathrm{K}$ doses via fertigation on papaya characters: total fruit weight (TFW); yield of marketable fruits (YMF); total number of fruits harvested (NFH); number of marketable fruits (NMF), fruit length (FL); fruit diameter (FD) and fruit weight (FW)

\begin{tabular}{|c|c|c|c|c|c|c|c|}
\hline \multirow{2}{*}{$\begin{array}{l}\text { Variation } \\
\text { Sources }\end{array}$} & \multicolumn{7}{|c|}{ Variables } \\
\hline & TFW & YMF & $\mathrm{NFH}$ & $\mathrm{NMF}$ & FL & FD & FW \\
\hline $\mathrm{K}$ doses & $\begin{array}{c}12,55^{*} \\
*\end{array}$ & $7,93^{*}$ & $6,21 *$ & $10,44 * *$ & $4,84 *$ & $1,05^{\mathrm{NS}}$ & $12,24 * *$ \\
\hline Block & $0,21^{\mathrm{NS}}$ & $0,69^{\mathrm{NS}}$ & $0,22^{\mathrm{NS}}$ & $0,45^{\mathrm{NS}}$ & $0,73^{\mathrm{NS}}$ & $3,14^{\mathrm{NS}}$ & $1,11^{\mathrm{NS}}$ \\
\hline Linear Reg. & $\begin{array}{c}17,44^{*} \\
*\end{array}$ & $5,86^{*}$ & $4,78^{\mathrm{NS}}$ & $14,52 * *$ & $0,063^{\mathrm{NS}}$ & $1,17^{\mathrm{NS}}$ & $0,316^{\mathrm{NS}}$ \\
\hline Polyn. Reg. & $\begin{array}{c}19,69 * \\
*\end{array}$ & $17,94 * *$ & $12,21 * *$ & $15,46^{* *}$ & $12,20 * *$ & $1,88^{\mathrm{NS}}$ & $35,51 * *$ \\
\hline Cubic Reg. & $0,520^{\mathrm{NS}}$ & $0,021^{\mathrm{NS}}$ & $1,65^{\mathrm{NS}}$ & $1,34^{\mathrm{NS}}$ & $2,26^{\mathrm{NS}}$ & $0,11^{\mathrm{NS}}$ & $0,90^{\mathrm{NS}}$ \\
\hline V.C. & 2,86 & 12,899 & 1,24 & 1,57 & 6,28 & 0,68 & 0,71 \\
\hline
\end{tabular}

$* *=1 \%$ probability $; *=5 \%$ probability $;$ and $\mathrm{NS}=$ non-significant at $5 \%$ probability

According to regression analysis, all variables that showed statistical difference adjusted to the polynomial regression model.

The ANOVA of fruit quality variables presented in Table 3 shows significant effect of $\mathrm{K}$ doses on soluble solids (SS), titratable acidity (TA) and SS/TA ratio while no statistical significance was detected for $\mathrm{pH}$. Similarly to the behavior of the biometric variables, the fruit quality variables adjusted to the polynomial regression model. 
Table 3. Effect of $\mathrm{K}$ doses via fertigation on variable related to papaya fruit quality; soluble solids (SS), $\mathrm{pH}$, titratable acidity (TA) and SS/TA ratio

Variables

Variation Sources

\begin{tabular}{lcccc} 
& $\mathrm{SS}$ & $\mathrm{pH}$ & $\mathrm{TA}$ & $\mathrm{SS} / \mathrm{TA}$ \\
\hline K doses & $4,28^{*}$ & $0,98^{\mathrm{NS}}$ & $4,96^{*}$ & $4,87^{*}$ \\
Block & $0,10^{\mathrm{NS}}$ & $1,60^{\mathrm{NS}}$ & $0,28^{\mathrm{NS}}$ & $0,33^{\mathrm{NS}}$ \\
Linear Reg. & $12,27^{* *}$ & $2,54^{\mathrm{NS}}$ & $1,06^{\mathrm{NS}}$ & $7,15^{*}$ \\
Quadratic Reg.. & $0,49^{\mathrm{NS}}$ & $3,64^{\mathrm{NS}}$ & $8,74^{*}$ & $7,28^{*}$ \\
Cubic Reg. & $0,10^{\mathrm{NS}}$ & $2,21^{\mathrm{NS}}$ & $0,18^{\mathrm{NS}}$ & $0,18^{\mathrm{NS}}$ \\
V. C. & 5,81 & 8,13 & 17,40 & 1,24 \\
\hline
\end{tabular}

$* *=1 \%$ probability; $*=5 \%$ probability; and $\mathrm{NS}=$ non-significant $5 \%$ at probability.

\subsection{Environmental Characteristics}

As stated elsewhere, environmental data were recorded using an automatic portable meteorological station (Vantage Pro2, Davis), set $5 \mathrm{~m}$ distant from the experimental field. According to Ramalho et al. (2011), annual rainfall around $1,550 \mathrm{~mm}$ to $2,000 \mathrm{~mm}$ and average temperature from 25 to $29 \mathrm{C}$ are ideal conditions for papaya development and production. In this regard, as shown in Figure 1, the environmental conditions during the conduction of the experiment can be considered within the papaya crop requirements.

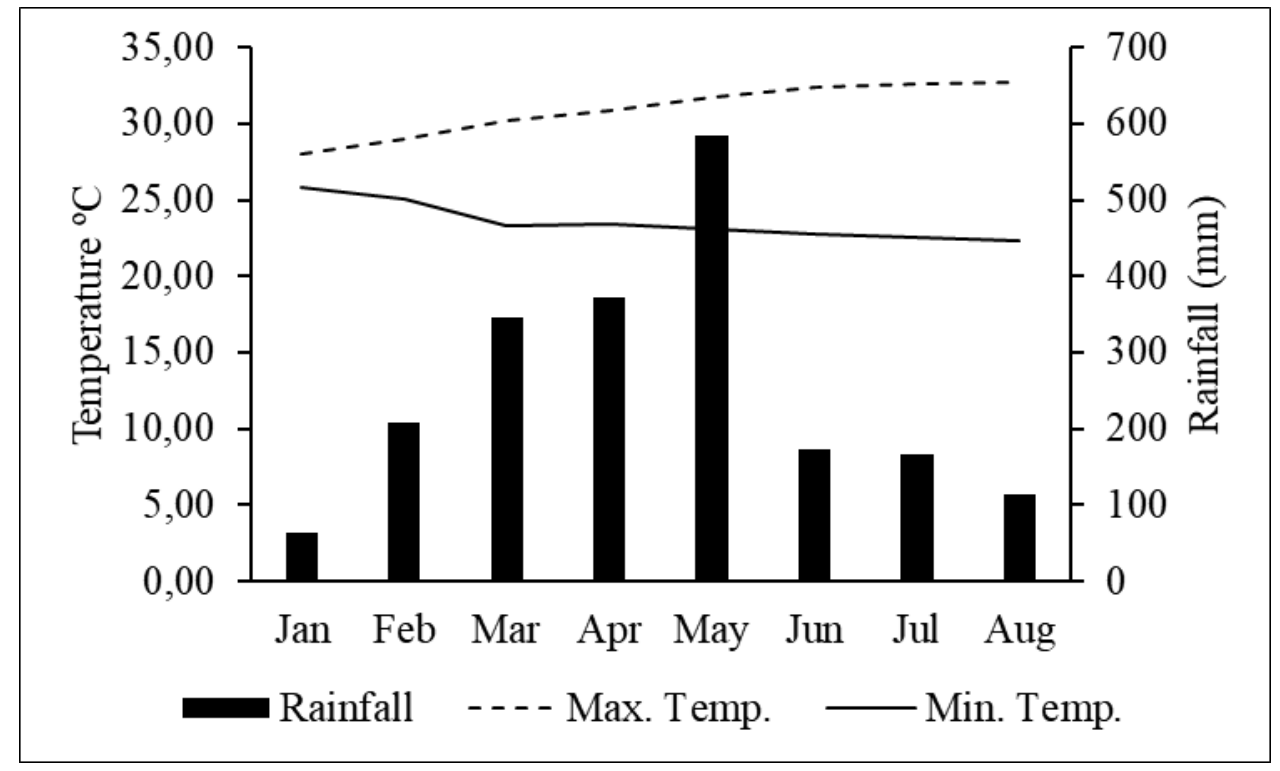

Figure 1. Environmental data recorded all over the period corresponding to the conduction of the experiment 


\subsection{Papaya Fruit Biometry}

Related to fruit biometry, both fruit length and fruit diameter variables showed significant response to $\mathrm{K}$ doses and were best adjusted to the polynomial regression model (Figure 2). Fruit length expressed maximum value at the $\mathrm{K}$ dose of $379.4 \mathrm{~kg}$ ha-1, reaching $127.1 \mathrm{~mm}$ (Figure 2A). Potassium doses higher than that caused reduction on the fruit length. Similar results were reported by Marinho et al. (2008), who evaluated papaya yield and fruit quality of papaya, Golden cultivar, under several irrigation water depth and $\mathrm{K}$ doses and found average fruit length of about $135.9 \mathrm{~mm}$. Fagundes \& Yamanishi (2001) as well as Reis et al. (2015) analyzing physical-chemical characteristics of papaya fruits also found fruit length varying from 124 to $145 \mathrm{~mm}$ and $139 \mathrm{~mm}$ respectively.


Figure 2. Papaya fruit length (FL) (a) and weight (FW) (b) in response to several doses of potassium supplied via fertigation

Fruit weight expressed maximum value at the $\mathrm{K}$ dose of $420.8 \mathrm{~kg}$ ha-1, reaching $418.6 \mathrm{~g}$ (Figure 2B). This is in accordance with results from several works conducted with Solo papaya, varying from 300 to $650 \mathrm{~g}$ (Dantas et al. 2015; Borges et al. 2018; Ledo et al. 2018; Barros et al 2017). In this work, the average fruit weight was around $420 \mathrm{~g}$, which is an accepted weight for both domestic and international markets. The Switzerland market prefers papaya fruits varying from 290 to $349 \mathrm{~g}$ while the German and French markets prefer papaya fruits in the range of 350 to $439 \mathrm{~g}$, and the Portuguese market prefers larger and heavier fruits, from 449 to $650 \mathrm{~g}$ (Balbino \& Costa, 2003).

It was observed that $\mathrm{K}$ influenced positively on physical characteristics of papaya fruits, cultivar THB, as a consequence of better fruit development. Potassium participate in several metabolic processes such as transfer of carbohydrates from the leaves to the fruits, improving fruit quality and increasing fruit size and weight. Potassium application to papaya crop in frequent doses promotes higher yields especially in high rainfall areas and medium-textured soils (Taiz et al. 2017).

\subsection{Yield and Fruit Number}

Data related to total yield (TY, $\mathrm{t} \mathrm{ha}^{-1}$ ), yield of marketable fruits (YMF, $\mathrm{t} \mathrm{ha}^{-1}$ ), total number of fruits harvested (NFH ha ${ }^{-1}$ ) and number of marketable fruits (NMF ha-1) are shown in Figure 3. For all those variables, the best adjustment was the polynomial regression model. 

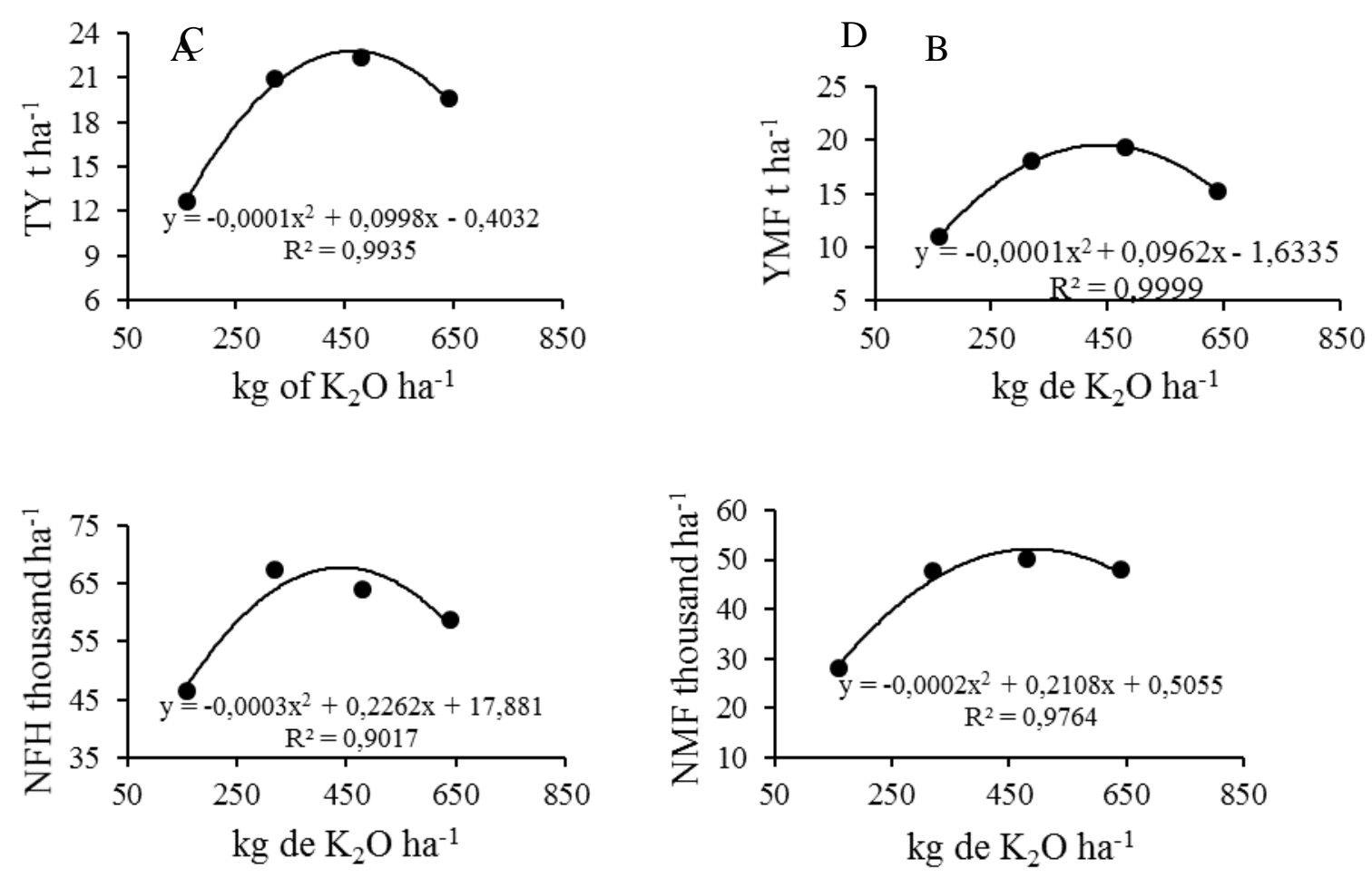

Figure 3. Papaya total yield (TY, $\mathrm{t} \mathrm{ha}^{-1}$ ) (a), yield of marketable fruits (YMF, $\mathrm{t} \mathrm{ha}^{-1}$ ) (b), total number of fruits harvested (NFH ha $\left.{ }^{-1}\right)(\mathrm{c})$ and number of marketable fruits (NMF ha-1) (d) in response to several doses of potassium supplied via fertigation

Data in Figure 3 show that potassium fertilization lower than the crop requirement has a negative effect on the papaya yield. This is probably due to that lower doses of $\mathrm{K}$ does not reach the required amount of that nutrient necessary for the papaya plant perform some metabolic pathways, such as those related to leaf area and growing point, thus impacting fruit number (Meurer et al., 2018). Data in Figure 3 show also that supplying amounts of K beyond the crop requirements does not increase yield. Besides increasing the production costs, the excess of $\mathrm{K}$, will not be taken up by the papaya plant making clear the importance of a well planned fertilization program for the papaya crop.

No difference was observed for yield of marketable fruits when potassium was supplied at the rate of $320 \mathrm{~kg} \mathrm{ha}^{-1}, 480 \mathrm{~kg} \mathrm{ha}^{-1} \mathrm{e} 640 \mathrm{~kg} \mathrm{ha}^{-1}$, resulting in average yield of 20,9 $\mathrm{t} \mathrm{ha}^{-1}, 22,3 \mathrm{t}$ ha-1 e 19,6 tha ${ }^{-1}$, respectively. The overall yield, except for the $\mathrm{K}$ dose of $160 \mathrm{~kg} \mathrm{ha}^{-1}$, were higher than the average papaya yield of the State of Pará, which was around $15 \mathrm{t} \mathrm{ha}^{-1}$ in 2018 (IBGE, 2018). According to the data obtained in this research, maximum papaya yield of 26.6 $\mathrm{t}$ ha-1would be obtained at the potassium dosage of $464.72 \mathrm{~kg} \mathrm{ha}^{-1}$ (Figure 3A). That maximum papaya yield is $57.3 \%$ superior to the average yield of the Sate of Pará.

As shown in Figure 3B, maximum yield of marketable fruits for this research is $19.5 \mathrm{tha}^{-1}$ corresponding to the potassium dose of $440 \mathrm{~kg} \mathrm{ha}^{-1}$. That value is $21 \%$ lower than the maximum total yield found in this work. However, it is important to mention that the maximum yield of marketable is superior to the average papaya yield of Para, thus showing 
that potassium fertilization, via fertigation, increases papaya yield. Those results indicate that, for maximum papaya yield in the region where this work was conducted, it is necessary high doses of potassium.

Although the values of total yield and marketable fruit yield obtained in this work are higher than de average papaya yield of the state of Para, they are lower than results reported by Albuquerque et al. (2019) and Dantas et al. (2015) who obtained papaya yields higher than 40 $\mathrm{t} \mathrm{ha}^{-1}$. That difference may be due to the high rainfall during de conduction of this experiment as reported by Barros et al. (2017) who found that, at winter season, papaya yield of both groups Formosa and Solo is inferior to that from summer season.

Figure $3 \mathrm{C}$ and $\mathrm{D}$ show results regarding to total number of fruits harvested and number of marketable fruits per hectare. As determined by the regression analysis, the maximum value for total number of fruits harvested per hectare is 67,776 corresponding to the potassium dose of $441 \mathrm{~kg} \mathrm{ha}^{-1}$. For the variable number of marketable papaya fruit per hectare the maximum value was determined to be 52,147 fruits $\mathrm{ha}^{-1}$, corresponding to the potassium dose of $490 \mathrm{~kg}$ $\mathrm{ha}^{-1}$. Those results show the importance of potassium availability to the papaya plant in order to favor good fruit development and quality. In this regard, potassium plays important roles on plant metabolism as enzyme activator, photosynthesis regulator, transport of nutrients and carbohydrate, and on the respiration process (Shimazaki et al. 2007; Meurer et al. 2018).

The number of marketable fruits obtained in this work are similar to the results reported by Rezende (2016) who evaluated yield and quality of papaya fruits under several plant densities. Whoever, it is slightly lower than the results found by Marinho et al. (2010) regarding to yield and fruit quality of the hybrid UENF/CALIMAN01 under several water depth and potassium doses.

\subsection{Fruit Quality}

Data regarding to soluble solids content (SS), titratable acidity (TA) and SS/TA ratio are shown in Figure 4. Potassium doses supplied via fertigation increased soluble solids content of the papaya fruits, thus resulting on a linear effect with values varying from 12.7 to $14.1 \mathrm{o}$ Brix, respectively for the lower and the highest potassium dose evaluated (Figure 4A). According to Havlin et al. (1993) the increase on SS due to high potassium doses may be due to the increase of $\mathrm{CO} 2$ absorption, as sugar, during the photosynthesis process. The SS values obtained is this work are higher than those found by Dantas et al. (2015) and Barros et al. (2017) and are similar to those reported by Reis et al. (2015). 

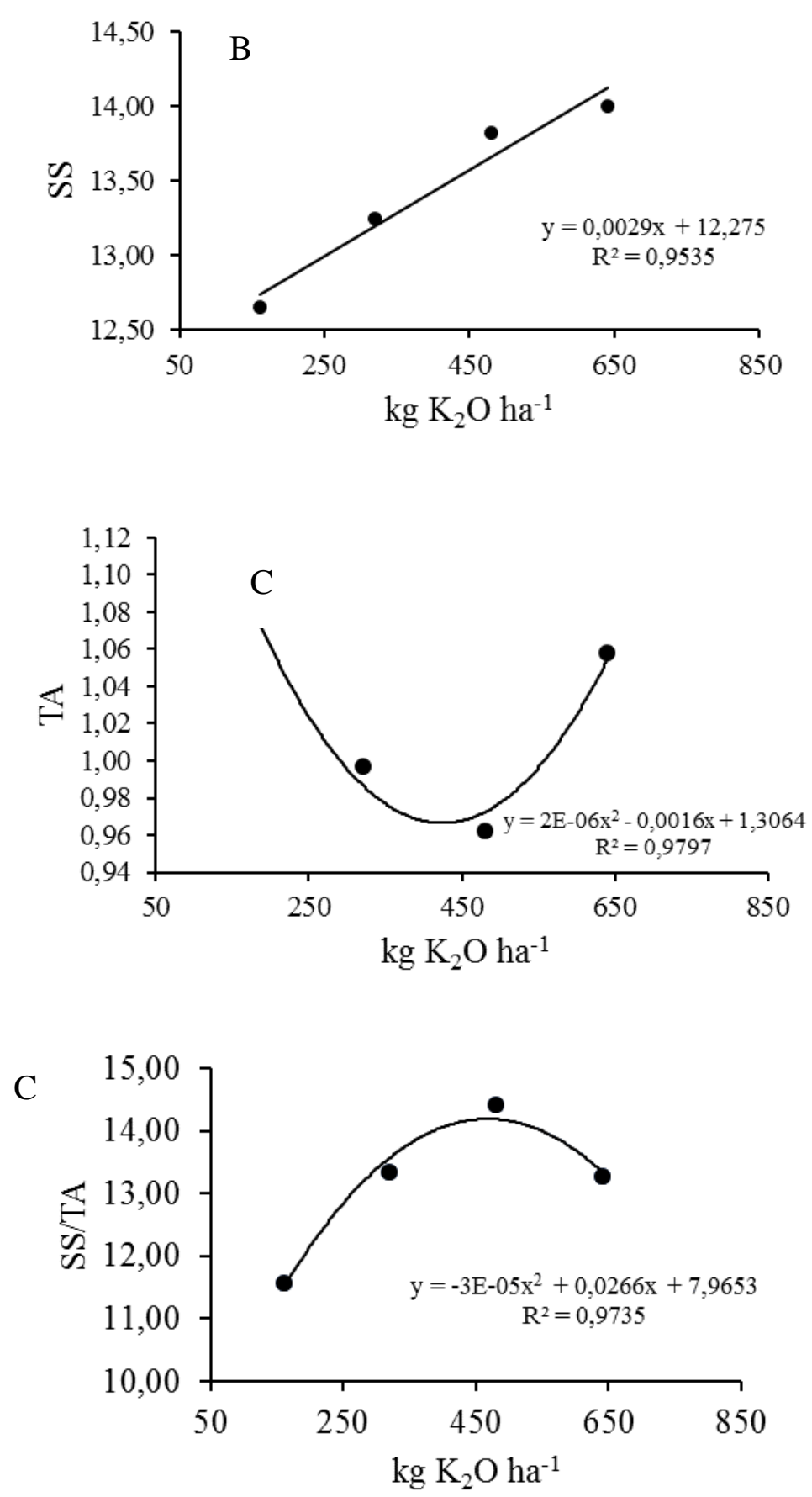

Figure 4. Soluble solid (SS) (a), titratable acidity (TA) (b) and SS/TA ratio (c) of papaya fruit and their relationship with potassium dose applied via fertigation

According to the Ministry of Agriculture, Livestock and Supply of Brazil, the minimum SS value of papaya fruit is $9.0^{\circ}$ Brix. Since the lower SS value obtained in the present work was $12.7^{\circ}$ Brix, the results are in accordance with that requirement.

The regression analysis regarding to the effect of doses of potassium on of the titratable acidity (TA) of the papaya fruit allowed the adjustment of that response to a quadratic model. The maximum TA value was 0.986 , corresponding to the potassium dose of $400 \mathrm{~kg} \mathrm{ha}^{-1}$ 
(Figure 4B). The results obtained in this work are similar to those found by Barros et al. (2017) studying the behavior of some papaya genotypes, Formosa group, under several planting times. On the other hand they are higher than the values reported by Dantas et al. (2015) who worked with several papaya hybrids and lineages.

For SS/TA ratio, the adjusted regression model was the quadratic one. For maximum SS/TA ratio it is necessary to apply $443.3 \mathrm{~kg}$ of potassium per hectare (Figure $4 \mathrm{C}$ ). Such a potassium dose is expected to promote the production of fruits with the best organoleptic characteristics in comparison with other potassium doses.

The SS/TA ratio obtained in this research is higher than those reported by Silva (2015) but they are in accordance with the findings by Ferraz (2012) working with Sunrise Solo papaya group.

Chitarra \& Chitarra (2005) state that the soluble solids and titratable acidity ratio is a very important indicator of fruit quality and flavor. During the ripening process there is an increase on sugar content and a reduction on acid content thus, as higher the SS/TA ratio as sweeter the fruit pulp.

\section{Conclusion}

Considering the conditions under the development of this work and the results obtained it is recommended the application of $440 \mathrm{~kg} \mathrm{ha}^{-1}$ of potassium to the papaya crop, via fertigation, in order to obtain better yield and fruit quality.

\section{Acknowledgement}

The first author was the financing of this field research, the Emater-PA for believing in the qualification of technicians, the UFRA for the support and the teacher Antonia Bronze for the help in data collection.

\section{References}

Albuquerque, G. H. S., Soares, I., Aquino, B. F., Miranda, F. R., \& Dutra, I. (2019). Evaluation of NPK doses on the production of papaya 'Caliman 01'. Revista Ciência Agronômica, 529-535. https://doi.org/10.5935/1806-6690.20190062

Araújo, R. C., Bruckner, C. H., Martinez, H. E. P., Salomão, L. C. C., Venegas, V. H. A., Dias, J. M. M., ... Souza, J. A. de (2005). Crescimento e produção do maracujazeiro-amarelo em resposta à nutrição potássica. Revista Brasileira de Fruticultura, 128-131. https://doi.org/10.1590/S0100-29452005000100034

Balbino, J. M. S., \& Costa, A. F. S. (2003). Crescimento e desenvolvimento dos frutos do mamoeiro do "grupo solo" e padrão de qualidade. In: MARTINS, D. dos S.; COSTA, A.F.S. da. (Ed.) A cultura do mamoeiro: tecnologias de produção, 389-402.

Barros, F. L. S., Kuhlcamp, K. T., Arantes, S. D. \& Moreira, S. O. (2017). Productivity and quality of Formosa and Solo papaya over two harvest seasons. Pesquisa agropecuária brasileira, 599-606. https://doi.org/10.1590/s0100-204x2017000800005 


\section{Macrothink}

Barros, G. B. de A., Aredes, F. A. S., Ramos, H. C. C., Catarina, R.S., \& Pereira, M. G. (2017). Combining ability of recombinant lines of papaya from backcrossing for sexual conversion. Rev Ciência Agronômica, 48, 166-174. https://doi.org/10.5935/1806-6690.20170019

Borges, V. P., Silva, J. R. R., Castro, A. M. O. B., Silva, S. O., \& Ledo, C. A. S. (2018). Caracterização agronômica de novos híbridos de mamoeiro. VII Simpósio do papaya brasileiro produção e sustentabilidade hídrica.

Coelho, E. F.; Oliveira, A. M. G.; Silva, J. G. F. DA; Coelho Filho, M. A.; Cruz, J. L. Irrigação e fertirrigação na cultura do mamão. In: Coelho, E. F.; Oliveira, A. M. G de;Silva, J. G.F da;Filho M. A. C.; Cruz J. L. Irrigação e fertirrigação em fruteiras e hortaliças. Brasília: Embrapa, 2014. Cap. 15. p. 425-457.

Chitarra, M. I. F.; Chitarra, A. B. (2005). Pós-colheita de frutos e hortaliças: fisiologia e manuseio. 2. ed. rev. e ampl. Lavras: UFLA.

Dantas, J. L. L., Lucena, R. S., \& Vilas Boas, S. A. (2015). Avaliação agronômica de linhagens e híbridos de mamoeiro. Revista Brasileira de Fruticultura, 138-148. https://doi.org/10.1590/0100-2945-022/14

Fagundes, G. R., \& Yamanishi, O. K. (2001). Características físicas e químicas de frutos de mamoeiro do grupo 'solo' comercializados em 4 estabelecimentos de Brasília-DF. https://doi.org/10.1590/S0100-29452001000300018

FAOSTAT. Food and Agriculture Organization of the United Nations. 2017. http://faostat3.fao.org/home/e Acesso em: de setembro de 2019.

Feitosa, E. O., Araújo, A. F. B., Lopes, F. B., Andrade, E. M., \& Bezerra, F. M. L. (2018). Análise de custo e rentabilidade na produção de mamão irrigado no semiárido. Revista Brasileira de Agricultura Irrigada, 2293-2304. https://doi.org/10.7127/rbai.v12n100686

Ferraz, R. A., Bardiviesso, D. M., \& Leonel, S. (2012). Caracterização físico-química das principais variedades de mamão 'solo' comercializadas na CEAGESP/SP. Magistra, Cruz das Almas, 24(3), 181-185.

IBGE - Instituo Brasileiro de Geografia e Estatística. Sidra - Produção Agrícola Municipal. 2018. <http:www.sidra.ibge. gov.br > Acesso em: 29. Setembro. 2019.

Instituto Brasileiro de Geografia e Estatística - produção agrícola municipal (IBGE - PAM). Disponível em: <sidra.ibge.gov.br/pesquisa/pam/tabelas. Acesso em: 15 set. 2018.

Ledo, C.A. S., Borges, V. P., Silva, S. O., Reis, R. C., Viana, E. S., \& Oliveira, A. M. G. (2018). Caracterização físico-química de frutos da linhagem elite de mamoeiro cmf 178. VII Simpósio do papaya brasileiro produção e sustentabilidade hídrica.

Lima, R. S. N., Figueiredo, F. A. M. M. A., Martins, A. O., Silva de Deus, B. C., Ferraz, T. M., Gomes, M. M. A., ... Campostrini, E. (2015). Partial rootzone drying (PRD) and regulated deficit irrigation (RDI) effects on stomatal conductance, growth, photosynthetic capacity, and 


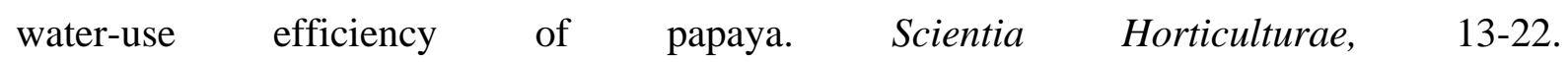
https://doi.org/10.1016/j.scienta.2014.12.005

Manica, I., Martins, D. S., \& Ventura, J. A. (2006). Mamão: Tecnologia de produção, póscolheita, exportação, mercados. Porto Alegre: Cinco Continentes, 2006. 361p.

Marinho, A. B., Bernardo, S., Sousa, E. F. de, Pereira, M. G., \& Monnerat, P. H. (2008). Produtividade e qualidade de frutos de mamão cultivar 'Golden' sob diferentes lâminas de irrigação e doses de potássio no norte de Espírito Santo. Engenharia Agrícola, 417-426. https://doi.org/10.1590/S0100-69162008000300003

Marinho, A. B., Bernardo, S., Sousa, E. F., Daher, R. F., Carvalho, C. M., \& Meireles, R. C. (2010). Produtividade e qualidade do fruto do mamoeiro híbrido UENF/Caliman 01 sob diferentes lâminas de irrigação e doses de potássio. Agropecuária Técnica, Areia. 22-28.

Meurer, E. J., Tiecher, T., Mattiello, L. Potássio. In: Fernandes, M. S., Souza, S. R., Santos, L. A. (2018). Nutrição mineral de plantas. Sociedade Brasileira de Ciência do Solo.

Oliveira, A. M. G., \& Caldas, R. C. (2004). Produção do mamoeiro em função de adubação com nitrogênio, fósforo e potássio. Revista Brasileira Engenharia Agrícola Ambiental. 160-163. https://doi.org/10.1590/S1415-43662004000100023

Oliveira, M. V. A. M. \& Vilas Bôas, R. L. (2008). Uniformidade de distribuição do potássio e do nitrogênio em sistema de irrigação por gotejamento. Engenharia Agrícola. 95-103. https://doi.org/10.1590/S0100-69162008000100010

Pacheco, N. A., \& Bastos, T. X., (2011). Boletim agrometereológico de 2008 para Igarapé-açú. Belém-PA:. Embrapa Amazônia Oriental. ISSN 1983-0513.

Ramalho, A. R., Souza, V. F., Silva, M. J. G. da, Junior, J. R. V., \& Cassaro, J. D. (2011). Condições agroclimáticas e riscos tecnológicos para cultura do mamoeiro em Rondônia. Embrapa Rondônia-Comunicado Técnico (INFORTECA-E). 2017.

Reis, R. C., Viana, E. de S., Jesus, J. L. de, Dantas, J. L. L., \& Lucena, R. S. (2015). Caracterização físico-química de frutos de novos híbridos e linhagens de mamoeiro. Pesquisa Agropecuária Brasileira, 210-217. https://doi.org/10.1590/S0100-204X2015000300004

Ritzinger, C. H. S. P., \& Souza, J. S. (2000). Mamão: Fitossanidade. Cruz das Almas: EMBRAPA, 91p.

Serrano, L. A. L. \& Cattaneo, L. F. (2010). O cultivo do mamoeiro no Brasil. Revista Brasileira de Fruticultura, 657-959. https://doi.org/10.1590/S0100-29452010000300001

Shimazaki, K. I., Michio, D., Sarah, M. A., \& Toshinori, K. (2007). Light regulation of stomatal movement. Annual Review of Plant Biology, 219-247. https://doi.org/10.1146/annurev.arplant.57.032905.105434

Silva, D. R. M. (2014). Fontes de adubação potássica foliar no mamoeiro e sua relação com a produtividade e qualidade dos frutos. 64 p. 2014. Dissertação - Universidade Federal do Ceará - UFC. 


\section{Macrothink}

Journal of Agricultural Studies

ISSN 2166-0379 2020, Vol. 8, No. 3

Silva, M. S., Ferraz, R. A., \& Leonel, S. (2015). Características físicas e físico-químicas de mamões 'Formosa' provenientes de diferentes regiões de cultivo. Revista Iberoamericana de Tecnología Postcosecha, Hermosillo, 16(1), 42-48.

Soares, A. G., Trugo, L. C., Botrel, N., \& Souza, L. F. da S. (2005). Reduction of internal browning of pineapple fruit (Ananas zomosus L.) by preharvest soil application of potassium. $\begin{array}{llll}\text { Postharvest Biology and 201-207. } & \end{array}$ https://doi.org/10.1016/j.postharvbio.2004.07.005

Sousa, V. F., Marouelli, W. A., Coelho, E. F., \& Pinto, J. M. \& Coelho Filho, M. A. (2014). Irrigação e fertirrigação em fruteiras e hortaliças. 2 ed., Brasilia, DF: Embrapa Informação Tecnológica, p. 771.

Taiz, L., Zeiger, E., Moller, I. M., \& Murphy, A. (2017). Fisiologia e desenvolvimento vegetal. Porto alegre: Artmed.

\section{Copyright Disclaimer}

Copyright for this article is retained by the author(s), with first publication rights granted to the journal.

This is an open-access article distributed under the terms and conditions of the Creative Commons Attribution license (http://creativecommons.org/licenses/by/4.0/). 